\title{
The Impacts of Government Grants on Firm Behaviors
}

\author{
Rui Chen* \\ Beijing Jingshan School \\ *Corresponding author. Email: cr_chen2021@126.com
}

\begin{abstract}
Government grants play a key role in the firm's innovation. It helps the firm to innovate products, improves the firm's development, and promotes the firm's growth. Based on a competition-based government grant program called Innovate UK, I find a significant relationship between government grants and firm behaviors. For the empirical analysis, I adopt OLS (Ordinary Least Square) regression models with the company and time fixed effects. Specifically, the data shows that winning a grant increase the firm's total asset, short-term liabilities, long-term liabilities, and the firm's intangible asset. By showing that government grants can accelerate the innovation and the growth of the firm and the firm's products to some extent, this paper highlights the government's role in shaping the firm's innovation behaviors.
\end{abstract}

\section{Keywords: Innovation, Government Grant, Firm Behaviors.}

\section{INTRODUCTION}

The government is believed to play a key role in promoting economic growth and innovation. Innovation activities are in general risky and prohibit the firm to invest in them. The firm is established to maximize the overall profits of the company. If an investment project is too risky, they are unwilling to invest as the expected payoff can't compensate for the huge investment costs. However, for society as a whole, a risky investment project is beneficial to society even though it fails because the failure provides valuable experience to other firms. Yet it is hard to persuade the firm to get involved with high-risk innovation activities because they are not paid by other the firm who are learning from them.

There are usually two methods that the government takes to tackle the problem: competition-based grants and subsidization. For competition-based grant programs, the government allocates the funds to the firm that are most capable of conducting innovative activities. For subsidization programs, the government allocates funds to the firm that meet certain eligibilities regardless of their capacity of conducting innovative research. Both methods have their pros and cons. For competition-based programs, they are more effective in allocating limited funds to the firm that are potentially more productive in generating the most valuable innovations. However, the evaluation process that selects the granted firm is based on judges' subjective assessment. It can involve corruption and abuse of funds. On the other hand, subsidization programs may not be as effective as competition-based grant programs, but they guarantee equality among the firm.

This paper takes advantage of a program sponsored by the UK government to examine the effectiveness of a competition-based grant program in spurring the firm's innovation and growth. The program is called Innovate UK. It welcomes applications with minimum requirements for research proposals about certain topics, for example, how to improve the efficiency of green energy and development medicine for cancers. The applicants are usually the firm that cooperate with universities and other academic institutions. They select proposals that are most competent to solve the proposed problem and allocate funds to them. Usually, the amount of grant can't exceed the claimed total cost.

It is unclear if such policy can increase the innovation activities, the firm growth and other performance of the firm. There are three scenarios about the outcomes. First, the policy is helpful to successful applicants. Because by getting the fund, the firm are not financially constrained anymore and are encouraged to invest in the research and development of the proposed projects. Second, the policy has no effects on the successful applicants. It is because the applicants are unnecessarily firms that are constrained by limited funding to invest. They will always invest a certain amount of money regardless of the government's grant. Third, the policy may have negative effects on successful applicants. It's simply 
because those firms who get the grant want to enjoy a "quiet an easy life" instead of getting devoted to busywork. Without the grant, they would have been hard working to earn money.

Because of the uncertainty of the actual effects of the policy, it highlights my investigation of the impacts of winning a grant from the government-sponsored program on the firm's growth, innovation, and other performance. In particular, I will take a rigorous empirical approach to answer the research question. These methods are built upon the Ordinary Least Square (OLS) regression model. I also include company fixed effects and time fixed effects to control for heterogeneity across the firm and over time. Essentially, the OLS method allows to me compare the performance of the firm that win and the firm that didn't win the competition.

This paper uses a case study to show the impact of the government grant on firm behaviors. It focuses on the program in the UK which is not studied before. The Innovate UK effectively avoids some irrelevant factors, for example, it avoids being influenced by government policies [1][2]. Generally, this paper contributes to the understanding of the firm's response to the government's intervention. The effects of government grants on firm are multi-dimension, they work as the manager in society, it controls the direction of society, includes innovation. Therefore, after understanding the relationship between government grants and the firm behaviors mentioned in this paper. The understanding between the firm and the government can be enhanced and the economy can be promoted.

The paper is organized in the following way. Section 2 is about the literature review; Section 3 is about the development of hypotheses for tests; Section 4 talks about the data and empirical methods; Section 5 is showing the main results and discussions. Section 6 concludes.

\section{LITERATURE REVIEW}

There is a strong relationship between economic growth and entrepreneurial activity. The decisive factor in improving entrepreneurial activity is innovation. After the firm's innovation, employment opportunities may increase. If more and more people get jobs in the innovation firm, the economy will grow. Because of this, the government has a motivation to grant the innovative firm. A study by Acs and Audretsch [3] examined some important innovation firms in twentieth century. According to their research, small firms contribute much of the innovation. Similar studies include [1][2]. These research the connection between economic growth and entrepreneurial activity.

In different countries, there are many examples of government sponsored programs aiming to promote firm growth and innovation.
There are some researches about the R\&D subsidy program in the US, the evaluation literature includes [4][5]. Bloom, Schankerman, and Van Reenen [6] use US tax credit changes to study $R \& D$ spillovers. The economists started to pay more attention on understanding the design of public subsidies for the innovative firm [7][8]. The roles of the Defense Advanced Projects Agency in supporting the development of early computer firms and the National Institutes of Health in promoting the fledgling biotechnology industry have been well documented [9].

There are some other studies address non-US R\&D programs in developed countries,includes [10] [11] [12] [13] [14]. Bond, Harhoff, and Van Reenen [15] 's researches build on the costly external financial literature which focused on large public companies and rarely studied R\&D. Universities and national labs must undertake basic R\&D. Startups which can efficiently conduct applied, market-oriented R\&D [16][17]. Acemoglu et al. [18] find that "optimal policy heavily relies on research subsidies." Similarly, the role of the Israeli Senor and Singer [19]'s research shows that chief scientist has been emulated by others, especially in catalyzing the creation of the nation's high-technology sector. Additionally, separate the firm's policymaker and the pressure of policy. This solution can reduce the pressure of the policymaker and let them decide without disturbance. This method has some achievements in some experiment, for example, the New Zealand Venture Investment Funds program [20]. Therefore, government grants may influence by policies rather than the innovative abilities of the firm. Match funds can be a great way to restrict the policymaker of the government to grant the valuable firm. For example: in June 1992, the Israeli government established Yozma Venture Capital Ltd., a $\$ 100$ million fund wholly owned by the public sector [19][21][22][23].

There is also a large literature on economics of corruption in developing countries. These literatures discuss the companies which connected with policies how to hamper rivals through connect wirh the government. (e.g., [24][25][26]). Pei[27]'s research shows that many outside observers validated that corruption is rampant in China and Chinese President $\mathrm{Xi}$ Jingping wages the anti-corruption campaign in recent years. Bertrand et al. [28]'s hypothesis is that corrupt government subsidies may simply represent wealth transfers that "grease the wheels of commerce."

Three aspects may let the government's effort fail. The first challenge is the geographic dilemma. Glaeser, Kerr, and Ponzetto [29]'s research shows that entrepreneurial businesses are often clustered geographically. Thus, it is difficult for the government to grant the most valuable firm. Then, is the timing dynamic, it comes from the boom-bust cycles in entrepreneurial markets. Lots of firms can get grants during some periods, but the valuable one cannot get funds during other periods. Therefore, the government's effort may fail. The last challenge is the human dimension. Some of nature of 
people are only associated with the greatest entrepreneur. However, some government officials cannot choose the correct entrepreneur to grant, hence the government grant may fail because the firm's operators, because they do not have the great nature of people. For instance, the research shows that both nearly all the entities will organize to capture the subsidies that handed out by public sector. However, most of the benefits will ended up with the person who is well-connected.[25]

My paper contributes to the literature mentioned above from several aspects.

At first, this paper uses a case study to conclude that the government investment in the innovative firm can bring a win-win situation to both the government and the firm. Hence, the discussion in this paper has some practical significance. Additionally, the case study uses the program in the UK which is not studied in previous literature. I think the UK can be different from the US (Such as the research about the R\&D subsidy program [4]), because firms face different constraints to growing and innovation. Then, the data and results of Innovate UK can prove that the decision of the firm should be based on its situation and should not be affected by other irrelevant factors. Like the research done by [1][2]. It also avoided from the timing dynamic. This program has been going on since 2004, so all the valuable firms can be granted whenever they do research and development. Generally, my paper contributes to the understanding of the firm's response to the government's intervention. From the literature, we are acknowledged that the effects of government grants on firms are multi-dimension. Bond, Harhoff, and Van Reenen [15]'s researches build on the costly external financial literature which focused on large public companies and rarely studied R\&D. The government encourages the firm to innovate and grant them. Therefore, the debt of innovative the firm declined and the investment in innovation increased. The firm shows a welcome attitude to such business inventions in the government. On the other hand, the government's invention in business is effective to some extent. The government works as the manager in society, it controls the direction of society, includes innovation. Like the roles of the Defense Advanced Projects Agency in supporting the development of early computer firms and the National Institutes of Health in promoting the fledgling biotechnology industry have been well documented. (e.g., [9]). Therefore, this paper can help the firm and the government to enhance understanding with each other and work together to promote economic growth.

\section{HYPOTHESIS DEVELOPMENT}

With my understanding of the literature, I develop several hypotheses to facilitate empirical design for my investigation about the effects of Innovate UK on firms. The hypothesis for this paper is the following:
Hypothesis 1: the impact of the government grant on the firm research and development is positive, this can help the firm to improve their technology.

Nowadays, lots of people start firms with very little initial funding, so most people choose to use the money to run the firm and they have no money to develop their products. Over time, it threatens the innovation and development of the firm. If the government can grant fundings to these the firm, the firms can relieve the financial pressure. After the firm receive money, they can use it for research and development, or improve their technology. Afterward, the firm can grow faster and more steadily. Under this hypothesis, the impact of the government grant on the firm research and development is positive, this can help the firm to improve their technology. The impact of government grants can also be negative if the fund has been corrupted or abused, the research and development of the firm will not be boosted. At the same time, the government also need to make sure the needs of markets and the development of the firm, or the grant may be ineffective.

Hypothesis 2: the impact of government grants on the firm total asset growth is positive.

Under the second hypothesis, the impact of government grants on the firm total asset growth is positive. The government grant money to firms can help them to increase their total asset and the money can be added to the total asset. The money that firms received from the government can improve their operations and also promoter their development. At the same time, the money can be used on the firm itself, like increase employee benefits or optimize the office environment. In addition, the government can be easier to achieve high cooperation with the firm that have been granted by the government before. So, it can help the government to innovate products and be better understand the market. For those grants to a higher degree of cooperation projects, the effect is stronger. For applications in teams, they can benefit more from the grant because the gain from their cooperation is larger than single-applicant applications. These measures of the government are in the positive support of the innovative firm so that the firm increase its total asset. However, if the government has certain conditions that companies need to meet and the conditions may reduce the total asset of the firm significantly, more than the amount invested by the government. The impact of the government growth on the firm total asset growth is negative.

Hypothesis 3: government grants can help the firm to reduce their short-term liabilities and long-term liabilities.

For the third hypothesis, government grants can help the firm to reduce their short-term liabilities and longterm liabilities. But there are no impacts for the firm with 
no liabilities. The grant of the government has different impacts on different companies. In terms of liabilities, the firm have taken out loans, so the grant can help them pay a part of their debts and try to help them be avoided from bankruptcy. It can also make the capital turnover of the firm more fluency and spend more time on innovation and take more risks and responsibilities, which is conducive to the development of the firm. But for the firm which have no loans, they have no worries about the liabilities. Hence the grant from the government can be added to the total asset that the firm have before and help them to the innovation and development. The same as the second hypothesis, if the grant cannot be used on the firm, the short-term liabilities and long-term liabilities cannot be reduced.

Hypothesis 4: firm's profitability is influenced by the products they produced after they are granted money by the government.

The firm can launch more products after being granted money from the governments, but not all the products will be accepted by customers. So, the innovative products which are popular among the customers can let the firm increase income and get more profits and the total asset of the firm may increase eventually. But if the products are not loved and affirmed by the public, so none of them would like to buy the products. Therefore, the profit of the firm may decline and the firm may even lose money. It can be seen that products innovation has a certain risk. So, it is necessary to do some feasible research and analyse the market. Under the fourth hypothesis, the firm's profitability is influenced by the products they produced after they are granted money by the government. If the products produced after the government granted have not influence the firm's profitability, the products may still be at the innovation stage and haven't developed new products. On the other hand, the production process may be interrupted and the products are not developed successfully.

\section{DATA AND EMPRICAL METHOD}

There are two data sources for my research. The first one is the data set about the competition and outcomes of the Innovate UK Program. The original data is from here: www.gov.uk/government/publications/innovate-ukfunded-projects. In Figure 1, it shows the number of winning companies and the total amount of grants from 2005 to 2020 in each quarter. While we see that there is a sharp decline in the number of winners in 2020 which might be caused by the outbreak of the COVID pandemic, I exclude the observations in 2020. I end up with a sample of 12050 winners, and $85 \%$ of them are companies. The data set also contains information on the start and end dates of the projects, the value granted to each company.
The second data source is the financial information of these companies. Companies incorporated in the UK will disclose their information in Companies House: findand-update.company-information.service.gov.uk.

I obtain the data from a database called FAME that keeps a record of the information.

The OLS model is the following:

$\ln \frac{y_{t}}{y_{t-1}}=b_{0}+b_{1} \times 1\left(\right.$ Grants $\left._{i, t}>0\right)+a_{t}+c_{i}+\epsilon_{i, t}$

In this model, $\ln \frac{y_{t}}{y_{t-1}}$ is the dependent Variable (or Outcome Variable), for example, the growth rate of total asset of the firm $i$ from year $\mathrm{t}-1$ to year 1 . The main independent variable (or explanatory variable) is an indicator variable that is equal to 1 if the firm $i$ wins any government-sponsored grant in year $t$, and equals to 0 otherwise. Also, I can use the amount of grants as the main independent variable. The results are similar to using the indicator as the independent variable. So, throughout the paper, the results shown are based on the OLS model that uses the indicator as the main regressor.

OLS regression stands for ordinary least squares regression. In statistics, OLS is a kind of method which estimates the parameters in a linear regression model. OLS follows the principle of least squares (minimize the sum of the squares of the difference value between the dependent variables which had been observed in the dataset and the independent variable which predicted by the linear function), chooses a group of parameters of a linear function of the set of explanatory variables.

$\mathrm{R}^{2}$ is the coefficient of determination indicating the goodness-of-fit of the regression. The value range of $\mathrm{R}^{2}$ is $[0,1]$. If the statistic is equal to one, the fit is perfect; if the statistic is equal to zero, the regressors $\mathrm{X}$ have no explanatory power. $\mathrm{R}^{2}$ will never decrease no matter the added regressors are irrelevant or not.

The standard error (use replacing the unknown quantity $\sigma^{2}$ with its estimate $s^{2}$ to estimate) of each coefficient $\widehat{\beta}_{J}$ is equal to the square root of the $\mathrm{j}$-th diagonal element of this matrix.

The square root:

$$
\widehat{s . e .}\left(\widehat{\beta}_{J}\right)=\sqrt{s^{2}\left(X^{T} X\right)_{j j}^{-1}}
$$

For the dependent variable, I take the logarithm growth instead of a simple growth rate. It's because we have the following relationship. By using logarithm growth, we can rule out outliers of the growth rate that takes extreme values.

$$
\ln \frac{y_{t}}{y_{t-1}} \approx \frac{y_{t}}{y_{t-1}}-1
$$


In addition, in the model, I consider time fixed effects $\left(a_{t}\right)$ and company fixed effects $\left(c_{i}\right)$. I include them because of two endogenous concerns. First, it's possible that the government has more competitions and offers more grants in times of good economic conditions. Then we observe the firm grow fast as well in these years as a result of good economic conditions instead of having the grants. So, we need to control for time-fixed effects. It eliminates the concern I just pointed out. Second, some firms are of better quality than other firms, and they are more likely to win a grant. Meanwhile, these high-quality firms have higher firm growth than other firms. Therefore, we cannot contribute the observed correlation between winning grants and the higher firm growth to a causal relationship. To solve the problem, I include company fixed effects, which allows me to control the firm quality.

The fixed effect model is a statistical model, it is in contrast to random-effects models and mixed models. Fixed effect model in econometrics and biostatistics is a regression model in which the group is non-random. Generally speaking, data can be grouped into several factors, and each group can be modelled as fixed or random effects for each grouping. Each group means is a group-specific fixed quantity in a fixed effect.

The key coefficient in the model is $b_{1}$. The sign of it tells us how sensitive the firm's performance to winning a grant. If $b_{1}$ is positive, winning a grant has positive effects on the firm; if $b_{1}$ is negative, winning a grant has negative effects on the firm; if $b_{1}$ is indifferent from 0 , winning a grant has no effects on the firm.

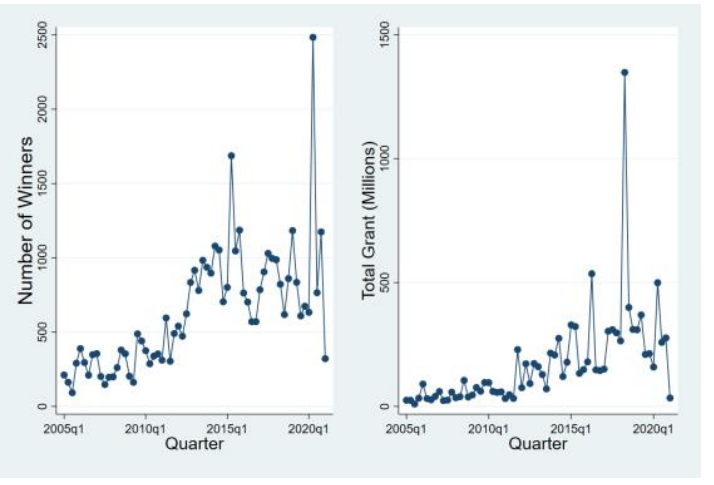

Figure 1 The Number of Winners and Total Grant Value by Quarter

\section{RESULTS AND DISCUSSIONS}

I measure the firm's performance from six different aspects. First, for the firm's growth, I measure the growth in the firm's total asset, current liabilities (short-term debt), and long-term liabilities (long-term debt). I find that all the results on these financial variables are significantly positive at $0.1 \%$ confidence interval. Moreover, the growth brought by having a grant for the total asset is $5.2 \%$, for short-term debt is $3.5 \%$ and for long-term debt is $5.6 \%$. These are the results when I have the full specification of the regression model (namely including time and company fixed effects). It can be observed that the inclusion of the fixed effects makes a difference to the results. For example, in columns (1) and (2) of Table 1. The inclusion of company fixed effects reduces the coefficients from $12.4 \%$ to $4.7 \%$. It implies there is an endogeneity problem. The higher-quality firm do get higher chances to win the competitions. When we compare columns (3) and (2) in this table, we see a slight increase in the coefficient. It suggests that there is some endogeneity problem in the time series. The government may offer more grants when the macroeconomy is bad. It's no surprise to see that short-term debt grows slower than long-term debt. It's because the grant is just like short-term debt.

The second dimension to look into the firm is its sales and profits (Table 4 and 5). These two may respond to having a grant if the innovation brings up new products and sales, for example, the key coefficients may increase or decline. However, in Table 4 and 5, the key coefficients are not significant in the full specification (column (3)). It just tells us that after the grant, the firm are still at the innovation stage and haven't developed new products so there will be no effects on sales and the firm's profitability. Even though the increase in sales and profits cannot be seen, innovation should still need to be valued, because it brings lots of possibilities to us. At the same time, the problems that happened before should be learned, which can make the innovation more effective this time.

The third aspect is about the intangible asset. The Intangible asset is the value of the firms' patents, trademarks, and etc., which measures the value of the firm's innovation activities. In Table 6 , the coefficients are positive $(5 \%)$. It provides direct evidence that the grant causes the firm to invest more in innovation, and help develop various products. The grant can also improve the vitality of the firm or even help to put the firm in a leading position.

My results validate the first three hypotheses and reject the last hypothesis mentioned earlier.

In Table 6, the key coefficients are positive, which means that the growth of the intangible asset is positive. Just like I had mentioned before that the intangible asset is the value of the firm's patents, trademarks, etc., which measures the value of the firm's innovation activities. It means that the ability of the firm research and development had increased after the government granted. Hence, my results validate the first hypothesis, there is a positive impact on the firm research and development after the government granted and the firm improve their technology through this. 
After the government granted, the fund and deposit of the firm increased, so the total asset of the firm increased. In Table 1, the growth brought by having a grant for the total asset is $5.2 \%$. The impact of government grants on the firm total asset growth is positive, the deposit increased, hypothesis 2 can be proved.

The third hypothesis can be validated. The firm can use the money granted by the government to do the research, so they do not need to be beholden to the bank. The debt declined because of this. In Table 2 and Table 3 , short-term debt is $3.5 \%$ and long-term debt is $5.6 \%$, so both short-term and long-term debt is reduced through helps by the government.
My results rejected the last hypothesis. Because of government grants, the firm has more abilities to do research and development. If the innovative product is popular among the customers, the firm's profitability will be increased; if the products cannot be accepted by customers, the profitability of firm will be declined. However, through Table 4 and Table 5, the key coefficients are not significant in the full specification. It just tells us that after the grant, the firm is still at the innovation stage and haven't developed new products so there will be no effects on sales and the firm's profitability.

Table 1. The Regression Results of Having Grant on Total Asset Growth

\begin{tabular}{cccc}
\hline & $(1)$ & $(2)$ & $(3)$ \\
\hline $1($ Grant $>0)$ & $0.124 * * *$ & $0.047^{* * *}$ & $0.052^{* * *}$ \\
& $(0.010)$ & $(0.011)$ & $(0.011)$ \\
Constant & $0.185^{* * *}$ & $0.191 * * *$ & $0.191^{* * *}$ \\
& $(0.004)$ & $(0.004)$ & $(0.004)$ \\
\hline Observations & 126311 & 125620 & 125620 \\
R2 & $0.12 \%$ & $14.43 \%$ & $15.63 \%$ \\
Company Fixed Effect & No & Yes & Yes \\
Time Fixed Effect & No & No & Yes \\
\hline Standard errors in parentheses & $=" * \mathrm{p}<0.05$ & $* * \mathrm{p}<0.01$ & $* * * \mathrm{p}<0.001 "$
\end{tabular}

Table 2. The Regression Results of Having Grant on Current Liabilities Growth

\begin{tabular}{cccc}
\hline & $(1)$ & $(2)$ & $(3)$ \\
\hline $1($ Grant $>0)$ & $0.074 * * *$ & $0.029 * * *$ & $0.035^{* * *}$ \\
& $(0.007)$ & $(0.008)$ & $(0.008)$ \\
& $0.103 * * *$ & $0.107 * * *$ & $0.106^{* * *}$ \\
Constant & $(0.003)$ & $(0.003)$ & $(0.003)$ \\
\hline Observations & 118643 & 117921 & 117921 \\
$\mathrm{R}^{2}$ & $0.10 \%$ & $10.55 \%$ & $11.17 \%$ \\
Company Fixed Effect & No & Yes & Yes \\
Time Fixed Effect & No & No & Yes \\
\hline Standard errors in parentheses & $=" * \mathrm{p}<0.05$ & $* * \mathrm{p}<0.01$ & $* * * \mathrm{p}<0.001 "$
\end{tabular}

Table 3. The Regression Results of Having Grant on Long Term Liabilities Growth

\begin{tabular}{cccc}
\hline & $(1)$ & $(2)$ & $(3)$ \\
\hline $1($ Grant $>0)$ & $0.065^{* * *}$ & $0.053 * * *$ & $0.056^{* * *}$ \\
& $(0.012)$ & $(0.014)$ & $(0.014)$ \\
Constant & $0.043^{* * *}$ & $0.044 * * *$ & $0.043 * * *$ \\
& $(0.005)$ & $(0.005)$ & $(0.005)$ \\
\hline Observations & 64616 & 63598 & 63598 \\
R2 & $0.04 \%$ & $10.67 \%$ & $10.82 \%$ \\
Company Fixed Effect & No & Yes & Yes \\
Time Fixed Effect & No & No & Yes \\
\hline Standard errors in parentheses & $=" * \mathrm{p}<0.05$ & $* * \mathrm{p}<0.01$ & $* * * \mathrm{p}<0.001 "$
\end{tabular}

Table 4. The Regression Results of Having Grant on Total Sales Growth 


\begin{tabular}{cccc}
\hline & $(1)$ & $(2)$ & $(3)$ \\
\hline $1($ Grant $>0)$ & $0.065^{* * *}$ & -0.001 & 0.003 \\
& $(0.008)$ & $(0.009)$ & $(0.009)$ \\
Constant & $0.184^{* * *}$ & $0.189 * * *$ & $0.188^{* * *}$ \\
& $(0.003)$ & $(0.003)$ & $(0.003)$ \\
\hline Observations & 99588 & 98699 & 98699 \\
R2 & $0.06 \%$ & $12.34 \%$ & $13.01 \%$ \\
Company Fixed Effect & No & Yes & Yes \\
Time Fixed Effect & No & No & Yes \\
\hline Standard errors in parentheses & $=" * \mathrm{p}<0.05$ & $* * \mathrm{p}<0.01$ & $* * * \mathrm{p}<0.001 "$ \\
\hline
\end{tabular}

Table 5. The Regression Result of Having Grant on Operating Profit Growth

\begin{tabular}{cccc}
\hline & $(1)$ & $(2)$ & $(3)$ \\
\hline $1($ Grant $>0)$ & 0.027 & 0.011 & 0.018 \\
& $(0.018)$ & $(0.021)$ & $(0.021)$ \\
Constant & $0.054 * * *$ & $0.054 * * *$ & $0.053 * * *$ \\
& $(0.007)$ & $(0.007)$ & $(0.007)$ \\
\hline Observations & 35519 & 34967 & 34967 \\
R2 & $00.01 \%$ & $8.85 \%$ & $9.16 \%$ \\
Company Fixed Effect & No & Yes & Yes \\
Time Fixed Effect & No & No & Yes \\
\hline Standard errors in parentheses & $=" * \mathrm{p}<0.05$ & $* * \mathrm{p}<0.01$ & $* * * \mathrm{p}<0.001 "$ \\
\hline
\end{tabular}

Table 6. The Regression Result of Having Grant on Intangible Asset Growth

\begin{tabular}{cccc}
\hline & $(1)$ & $(2)$ & $(3)$ \\
\hline $1($ Grant $>0)$ & $0.089 * * *$ & $0.043^{*}$ & $0.050^{* *}$ \\
& $(0.015)$ & $(0.017)$ & $(0.017)$ \\
Constant & $-0.022^{* * *}$ & $-0.016^{* *}$ & $-0.017 * *$ \\
& $(0.006)$ & $(0.006)$ & $(0.006)$ \\
\hline Observations & 30,655 & 30,045 & 30,045 \\
R2 & $0.12 \%$ & $16.92 \%$ & $17.34 \%$ \\
Company Fixed Effect & No & Yes & Yes \\
Time Fixed Effect & No & No & Yes \\
\hline Standard errors in parentheses & $=" * \mathrm{p}<0.05$ & $* * \mathrm{p}<0.01$ & $* * * \mathrm{p}<0.001 "$ \\
\hline
\end{tabular}

\section{CONCLUSION}

The government plays a key role in promoting economic growth, and the competition-based grants hold by the government is a great way to help the innovative firm. I use a program called Innovate UK which welcomes applications with minimum requirements for research proposals about certain topics. Through use the OLS regression model and include company fixed effects and time fixed effects, I compare the performance of firms that won and firms that did not win the competition.

I have found that in general, winning the governmentsponsored grant has positive effects on the firm. In particular, winning a grant increase the firm's total asset growth by $5.2 \%$ per year; it increases the firm's shortterm liabilities by $3.5 \%$; it increases the firm's long-term liability by $5.6 \%$; it also increases the firm's intangible 
asset's growth by $5 \%$. For sales and profit, there is no significant impact after I control for time fixed effects and company fixed effects. These patterns are consistent with the belief that the winners of these competitions do use the fund to invest in intellectual capital and it promotes the firm's growth.

These findings contribute to our understanding of the effectiveness of competition-based programs in helping the firm to grow. To shed some lights on policymakers, the allocation of funds should be competition-based to ensure efficiency. Moreover, if policy makers can restrict the competition to firm that are financially constrained, the effects of such programs might be even better.

\section{REFERENCES}

[1] Aron, Debra J., and Edward P. Lazear. "The introduction of new products." The American Economic Review 80.2 (1990): 421-426.

[2] Prusa, Thomas J., and James A. Schmitz Jr. "Can companies maintain their initial innovative thrust? A study of the PC software industry." The Review of Economics and Statistics (1994): 523-540.

[3] Acs, Zoltan J., and David B. Audretsch. "Innovation in large and small firms: an empirical analysis." The American economic review (1988): 678-690.

[4] Lerner, Josh. "The government as venture capitalist: the long-run impact of the SBIR program." The Journal of Private Equity 3.2 (2000): 55-78.

[5] Wallsten, Scott J. "The effects of governmentindustry $R \& D$ programs on private $R \& D$ : the case of the Small Business Innovation Research program." The RAND Journal of Economics (2000): 82-100.

[6] Bloom, Nicholas, Mark Schankerman, and John Van Reenen. "Identifying technology spillovers and product market rivalry." Econometrica 81.4 (2013): 1347-1393.

[7] Howell, Sabrina T. "Financing innovation: Evidence from R\&D grants." American Economic Review 107.4 (2017): 1136-64.

[8] Wang, Yanbo, Jizhen Li, and Jeffrey L. Furman. "Firm performance and state innovation funding: Evidence from China's Innofund program." Research Policy 46.6 (2017): 1142-1161.

[9] Mazzucato, Mariana. "Financing innovation: creative destruction vs. destructive creation." Industrial and Corporate Change 22.4 (2013): 851-867.

[10] Lach, Saul. "Do R\&D subsidies stimulate or displace private R\&D? Evidence from Israel." The journal of industrial economics 50.4 (2002): 369-390.
[11] Almus, Matthias, and Dirk Czarnitzki. "The effects of public R\&D subsidies on firms' innovation activities: the case of Eastern Germany." Journal of Business \& Economic Statistics 21.2 (2003): 226236.

[12] Bronzini, Raffaello, and Eleonora Iachini. "Are incentives for R\&D effective? Evidence from a regression discontinuity approach." American Economic Journal: Economic Policy 6.4 (2014): $100-134$

[13] Jaffe, Adam B., and Trinh Le. The impact of $R \& D$ subsidy on innovation: a study of New Zealand firms. No. w21479. National Bureau of Economic Research, 2015.

[14] Bronzini, Raffaello, and Paolo Piselli. "The impact of R\&D subsidies on firm innovation." Research Policy 45.2 (2016): 442-457.

[15] Bond, Stephen, Dietmar Harhoff, and John Van Reenen. "Investment, R\&D and financial constraints in Britain and Germany." Annales d'Economie et de Statistique (2005): 433-460.

[16] Griliches, Zvi. "Introduction to" R\&D and Productivity: The Econometric Evidence"." $R \& D$ and productivity: The econometric evidence. University of Chicago Press, 1998. 1-14.

[17] Aghion, Philippe, Mathias Dewatripont, and Jeremy C. Stein. "Academic freedom, private-sector focus, and the process of innovation." The RAND Journal of Economics 39.3 (2008): 617-635.

[18] Acemoglu, Daron, et al. "Import competition and the great US employment sag of the 2000s." Journal of Labor Economics 34.S1 (2016): S141-S198.

[19] Senor, Dan, and Saul Singer. Start-up nation: The story of Israel's economic miracle. Random House Digital, Inc., 2011.

[20] Lerner, Josh, David Moore, and Stuart Shepherd. "A study of New Zealand's venture capital market and implications for public policy." Report to the Ministry of Research Science \& Technology, LECG Limited, New Zealand (2005).

[21] Avnimelech, Gil, Martin Kenney, and Morris Teubal. "Building venture capital industries: Understanding the US and Israeli experiences." Available at SSRN 2758198 (2004).

[22] OECD, Paris, J. C. Dumont, and G. Lemaître. Trends in Migration. OECD, Paris, 2003.

[23] Trajtenberg, Manuel. "Government support for commercial R\&D: Lessons from the Israeli experience." Innovation policy and the economy 2 (2002): 79-134. 
[24] Khwaja, Asim Ijaz, and Atif Mian. "Do lenders favor politically connected firms? Rent provision in an emerging financial market." The Quarterly Journal of Economics 120.4 (2005): 1371-1411.

[25] Akcigit, Ufuk, Salomé Baslandze, and Francesca Lotti. Connecting to power: political connections, innovation, and firm dynamics. No. w25136. National Bureau of Economic Research, 2018.

[26] Shleifer, Andrei, and Robert W. Vishny. The grabbing hand: Government pathologies and their cures. Harvard University Press, 1998.

[27] Pei, Minxin. China's crony capitalism. Harvard University Press, 2017.

[28] Bertrand, Marianne, et al. "Obtaining a driver's license in India: an experimental approach to studying corruption." The Quarterly Journal of Economics 122.4 (2007): 1639-1676.

[29] Glaeser, Edward L., William R. Kerr, and Giacomo AM Ponzetto. "Clusters of entrepreneurship." Journal of urban economics 67.1 (2010): 150-168. 